\title{
PENYIMPANGAN PERILAKU REMAJA YANG MENIMBULKAN FENOMENA SOSIAL PADA MASYARAKAT KELURAHAN 9 ILIR LORONG KEMAS KOTA PALEMBANG
}

\author{
Salsabilah \\ Program Studi Sosiologi, Universitas Sriwijaya \\ Email: salsabilahbella286@gmail.com
}

\begin{abstract}
Deviation of behavior in adolescents with various forms of behavior that exceed the limits has become a social phenomenon at this time and makes society uneasy. There are many causes for juvenile delinquency. This deviant behavior also cannot be tolerated continuously and must be given a solution to deviant behavior through real actions. This article research uses qualitative methods using a case study approach. The data obtained in this study were obtained through two sources, namely through the literature study method where data were obtained from journals, articles, and others. Second, through observation so that the author can directly observe the deviant behavior of adolescents in the sub-district 9 Ilir, the container hall, Palembang, South Sumatra.
\end{abstract}

Keywords: behavioral deviations, deviance solutions, juvenile delinquency

\section{PENDAHULUAN}

Masa alih transisi dari anak- anak menuju dewasa atau biasa yang disebut remaja erat kaitannya dengan berbagai fenomena - fenomena sosial pada perilaku remaja itu sendiri mulai dari perilaku yang baik maupun perilaku yang melanggar norma - norma sosial pada masyarakat atau yang biasa disebut penyimpangan perilaku. Masa remaja yang digunakan untuk mencari jati diri dan identitas diri sering dilakukan dengan metode coba - coba tanpa pertimbangan yang matang sehingga menimbulkan kesalahan yang menyebabkan kemorosotan moral dan terciptanya penyimpangan perilaku, faktor lain yang menyebabkan penyimpangan perilaku pada remaja adalah pendidikan agama yang kurang, kurang nya perhatian orang tua dan lain sebagainya.

Pada masa sekarang ini penyimpangan perilaku pada remaja telah membuat resah masyarakat karena kenakalan remaja pada telah melampaui batas-batas norma sosial kemudian merambah pada tindakan - tindakan 
kriminalitas seperti pencurian, minum minuman keras, penyalah gunaan narkoba, pergaulan bebas, berjudi dan lain sebagai nya. Pemerintah sebagai pihak yang mempunyai wewenang untuk membangun bangsa telah menyadari bahwa percuma membangun sektor - sektor pendidikan dengan memfasilitasi remaja menggunakan berbagai program pendidikan seperti dana bos, bidik misi, beasiswa LPDP dan lain sebagainya apabila tidak membangun pendidikan karakter pada remaja itu sendiri.

\section{METODE PENELITIAN}

Penelitian artikel ini dengan menggunakan metode kualitatif dengan menggunkan pendekatan studi kasus. Penelitian kualitatif adalah penelitian yang bersifat deskriptif dan cenderung menggunakan analisis. Landasan teori dimanfaatkan sebagai pemandu agar fokus penelitian sesuai pada fakta di lapangan. Data - data yang didapatkan pada penelitian ini didapatkan melalui dua sumber yaitu melalui metode studi literatur yang mana data didapatkan dari jurnal, artikel, dan lain sebagai nya. Kedua, melalui observasi sehingga penulis dapat mengamati langsung perilaku penyimpangan pada remaja di kecamatan 9 ilir lorong kemas kota Palembang Sumatera Selatan.

\section{HASIL DAN PEMBAHASAN}

\section{Penyimpangan Perilaku}

Perilaku menyimpang dapat dimaknai sebagai perilaku kecenderungan untuk menyimpang dari suatu norma atau tidak patuh terhadap suatu norma terntentu (Selo Soemardjan, Ilmuawan Sosiologi Indonesia). Sementra itu, Luwis Coser mengemukakan bahwa perilaku menyimpang adalah salah satu cara untuk menyesuaikan kebudayaan dengan perubahan sosial. Kenakalan Remaja adalah gejala patologis sosial pada remaja yang disebabkan oleh satu bentuk pengabaian sosial. Akibatnya, mereka mengembangkan bentuk perilaku yang menyimpang. (Kartono, ilmuwan sosiologi).

Para ahli sependapat bahwa remaja adalah mereka yang berusia 13 - 18 tahun. Pada usia tersebut seseorang sudah melampaui batas anak - anak. Usia remaja juga terdiri dai bebarapa tahap :

(1) Tahap pra-pubertas (12 - 13 tahun)

Tahap ini disebut juga masa pueral, yaitu masa peralihan dari kanak-kanak ke remaja. Pada anak perempuan, masa ini lebih singkat dibandingkan dengan anak laki-laki. Pada tahap ini, terjadi perubahan yang besar pada remaja, yaitu meningkatnya hormon seksualitas dan mulai berkembangnya organ-organ seksual serta organ-organ reproduksi remaja. Di samping itu, perkembangan intelektualitas yang sangat pesat juga terjadi pada fase ini. Selain itu, pada masa ini remaja juga cenderung lebih berani mengutarakan keinginan hatinya, lebih 
berani mengemukakan pendapatnya, bahkan akan mempertahankan pendapatnya sekuat mungkin. Hal ini yang sering ditanggapi oleh orang tua sebagai pembangkangan. Remaja tidak ingin diperlakukan sebagai anak kecil lagi.

Mereka lebih senang bergaul dengan kelompok yang dianggapnya sesuai dengan kesenangannya. Mereka juga semakin berani menentang tradisi orang tua yang dianggapnya kuno dan tidak/kurang berguna, maupun peraturan-peraturan yang menurut mereka tidak beralasan, seperti tidak boleh mampir ke tempat lain selepas sekolah, dan sebagainya. Mereka akan semakin kehilangan minat untuk bergabung dalam kelompok sosial yang formal, dan cenderung bergabung dengan teman-teman pilihannya. Misalnya, mereka akan memilih main ke tempat teman karibnya daripada bersama keluarga berkunjung ke rumah saudara.

Tapi, pada saat yang sama, mereka juga butuh pertolongan dan bantuan yang selalu siap sedia dari orang tuanya, jika mereka tidak mampu menjelmakan keinginannya. Pada saat ini adalah saat yang kritis. Jika orang tua tidak mampu memenuhi kebutuhan psikisnya untuk mengatasi konflik yang terjadi saat itu, remaja akan mencarinya dari orang lain. Perhatian seolah-olah orang tua mengerti bahwa masalah itu berat sekali bagi remajanya, akan terekam dalam otak remaja itu bahwa orang tuanya adalah jalan keluar ang terbaik baginya. Ini akan mempermudah orang tua untuk mengarahkan perkembangan psikis anaknya.

(2) Tahap pubertas (14 - 16 tahun)

Tahap ini disebut juga masa remaja awal, dimana perkembangan fisik mereka begitu menonjol. Remaja sangat cemas akan perkembangan fisiknya, sekaligus bangga bahwa hal itu menunjukkan bahwa ia memang bukan anak-anak lagi. Pada tahap ini, emosi remaja menjadi sangat labil akibat dari perkembangan hormon-hormon seksualnya yang begitu pesat. Keinginan seksual juga mulai kuat muncul pada masa ini. Pada remaja wanita ditandai dengan datangnya menstruasi yang pertama, sedangkan pada remaja pria ditandai dengan datangnya mimpi basah yang pertama. Remaja akan merasa bingung dan malu akan hal ini, sehingga orang tua harus mendampinginya serta memberikan pengertian yang baik dan benar tentang seksualitas. Jika hal ini gagal ditangani dengan baik, perkembangan psikis mereka khususnya dalam hal pengenalan diri/gender dan seksualitasnya akan terganggu.

Kasus-kasus gay dan lesbi banyak diawali dengan gagalnya perkembangan remaja pada tahap ini. Di samping itu, remaja mulai mengerti tentang gengsi, penampilan, dan daya tarik seksual. Karena kebingungan mereka ditambah labilnya emosi akibat pengaruh perkembangan seksualitasnya, remaja sukar diselami perasaannya. Kadang mereka bersikap kasar, kadang lembut. Kadang suka melamun, di lain waktu dia begitu ceria. Perasaan sosial remaja di masa ini semakin kuat, dan mereka bergabung dengan kelompok yang disukainya dan membuat peraturan- peraturan dengan pikirannya sendiri. 
(3) Tahap akhir pubertas (17 - 18 tahun)

Pada tahap ini, remaja yang mampu melewati masa sebelumnya dengan baik, akan dapat menerima kodratnya, baik sebagai laki-laki maupun perempuan. Mereka juga bangga karena tubuh mereka dianggap menentukan harga diri mereka. Masa ini berlangsung sangat singkat. Pada remaja putri, masa ini berlangsung lebih singkat daripada remaja pria, sehingga proses kedewasaan remaja putri lebih cepat dicapai dibandingkan remaja pria. Umumnya kematangan fisik dan seksualitas mereka sudah tercapai sepenuhnya. Namun kematangan psikologis belum tercapai sepenuhnya.

(4) Tahap remaja adolesen (19 - 21 tahun)

Pada tahap ini remaja sudah mencapai kematangan yang sempurna, baik segi fisik, emosi, maupun psikisnya. Mereka akan mempelajari berbagai macam hal yang abstrak dan mulai memperjuangkan suatu idealisme yang didapat dari pikiran mereka. Mereka mulai menyadari bahwa mengkritik itu lebih mudah daripada menjalaninya. Sikapnya terhadap kehidupan mulai terlihat jelas, seperti cita-citanya, minatnya, bakatnya, dan sebagainya. Arah kehidupannya serta sifat-sifat yang menonjol akan terlihat jelas pada fase ini.

Kenakalan remaja biasanya dilakukan oleh remaja-remaja yang gagal dalam menjalani proses-proses perkembangan jiwanya, baik pada saat remaja maupun penyimpangan perilaku pada remaja terdiri dari berbagai bentuk antara lain : (1)Pencurian. Kasus - kasus pencurian yang terjadi pada masyarakat di masa sekarang ini sering kali dilakukan oleh remaja. (2) Tawuran. Tawuran antar kelurahan 9 ilir dan kelurahan 13 ilir sering terjadi tiap kali menjelang bulan puasa. Twuran ini diwarnai dengan senjata tajam, lemparn batu, maupun tembak - tembaakan kembang api. Fenomena tawuran pada remaja ini begitu meresahkan warga sekitar sehingga menimbulkan konflik sosial baru pada masyarakat di lorong kemas seperti pihak A yang menyudutkan B bahwa mereka tidak mampu mendidik anak mereka dengan baik sehingga terjadi tawuran. Kemudian, pihak B yang balik menuduh pihak A bahwa anak merekalah yang menyebabkan tawuran antar kelurahan ini terjadi. (3) Minum - minuman keras dan penyalahgunaan narkoba. (4) Pergaulan bebas.

Kematangan organ reproduksi pada remaja ditandai dengan adanya rasa tertarik dengan lawan jenis dan akan sangat berpengaruh terhadap perilaku seksual individu remaja. Pergaulan bebas yang menyebabkan Free sex, sehingga terjadi kehamilan di luar nikah pada remaja adalah betuk perilaku menympang remaja saat ini. Apabila penyimpangan seks terjadi pada usia sekolah maka akan berdampak pada kelangsungan masa depannya. Pertama, remaja akan mendapatkan sangsi dari sekolah (dikeluarkan) sehingga drop out tidak bisa melanjutkan pendidikannya yang merupakan bekal masa depannya dan kedua, lingkungan masyarakat akan memberikan sangsi sosial seperti mencemooh dan 
mengucilkannya. Sangsi sosial berlangsung seumur hidup dan merupakan aib yang tidak akan hilang selamanya. Secara psikologis, remaja akan merasa malu dan apabila tidak kuat bisa tertekan atau bunuh diri.

\section{Penyebab kenakalan remaja}

Ada dua faktor yang menjadi penyebab penyimpangan perilaku pada remaja yaitu faktor internal dan faktor eksternal.

\section{Faktor Internal}

a. Krisis identitas

Perubahan biologis dan sosiologis pada diri remaja memungkinkan terjadinya dua bentuk integrasi. Pertama, terbentuknya perasaan akan konsistensi dalam kehidupannya. Kedua, tercapainya identitas peran. Kenakalan remaja terjadi karena remaja gagal mencapai masa integrasi kedua.

b. Kontrol diri yang lemah

Remaja yang tidak bisa mempelajari dan membedakan tingkah laku yang dapat diterima dengan yang tidak dapat diterima akan terseret pada perilaku 'nakal'. Begitupun bagi mereka yang telah mengetahui perbedaan dua tingkah laku tersebut, namun tidak bisa mengembangkan kontrol diri untuk bertingkah laku sesuai dengan pengetahuannya.

\section{Faktor eksternal}

a. Kurangnya perhatian dari orang tua, serta kurangnya kasih sayang

Keluarga merupakan unit sosial terkecil yang memberikan fondasi primer bagi perkembangan anak. Sedangkan lingkungan sekitar dan sekolah ikut memberikan nuansa pada perkembangan anak. Karena itu baik-buruknya struktur keluarga dan masyarakat sekitar memberikan pengaruh baik atau buruknya pertumbuhan kepribadian anak. Keadaan lingkungan keluarga yang menjadi sebab timbulnya kenakalan remaja seperti keluarga yang broken-home, rumah tangga yang berantakan disebabkan oleh kematian ayah atau ibunya, keluarga yang diliputi konflik keras, ekonomi keluarga yang kurang, semua itu merupakan penyebab yang menimbulakn penyimpangan perilaku pada remaja.

b. Minimnya pemahaman tentang keagamaan

Dalam kehidupan berkeluarga, kurangnya pembinaan agama juga menjadi salah satu faktor terjadinya kenakalan remaja. Dalam pembinaan moral, agama mempunyai peranan yang sangat penting karena nilai-nilai moral yang datangnya dari agama tetap tidak berubah karena perubahan waktu dan tempat. Kondisi masyarakat sekarang yang sudah begitu mengagungkan ilmu pengetahuan mengakibatkan kaidah-kaidah moral dan tata susila yang dipegang teguh oleh orang-orang dahulu menjadi tertinggal di belakang. Dalam masyarakat yang telah terlalu jauh dari agama, kemerosotan moral orang dewasa sudah lumrah terjadi. Kemerosotan moral, tingkah laku dan perbuatan - perbuatan orang dewasa yang 
tidak baik menjadi contoh atau tauladan bagi anak-anak dan remaja sehingga berdampak timbulnya kenakalan remaja.

Faktor lain yang menjadi penyebab penyimpangan perilaku pada remaja adalah masalah khas remaja, yaitu masalah yang timbul akibat status yang tidak jelas pada remaja, seperti masalah pencapaian kemandirian, kesalahpahaman atau penilaian berdasarkan stereotip yang keliru.

\section{Solusi Penyimpangan Perilaku}

\section{Tindakan Preventif}

Usaha pencegahan timbulnya kenakalan remaja secara umum dapat dilakukan melalui cara berikut: (1) Mengenal dan mengetahui ciri umum dan khas remaja, (2) Mengetahui kesulitan-kesulitan yang secara umum dialami oleh para remaja. Kesulitan-kesulitan mana saja yang biasanya menjadi sebab timbulnya pelampiasan dalam bentuk kenakalan.

Usaha pembinaan remaja dapat dilakukan melalui: (1) Menguatkan sikap mental remaja supaya mampu menyelesaikan persoalan yang dihadapinya, (2) Memberikan pendidikan bukan hanya dalam penambahan pengetahuan dan keterampilan melainkan pendidikan mental dan pribadi melalui pengajaran agama, budi pekerti dan etiket.

Melalui Pendidikan agama ataupun moral pada remaja di dalam rumah tangga perlu dilakukan sejak kecil sesuai dengan umurnya karena setiap anak yang dilahirkan belum mengerti mana yang benar dan mana yang salah, juga belum mengerti mana batas-batas ketentuan moral dalam lingkungannya. Karena itu pendidikan moral pada permulaannya dilakukan di rumah tangga dengan latihan-latihan, nasehat-nasehat yang dipandang baik.

Maka pendidikan moral harus dimulai dari orang tua melalui teladan yang baik berupa hal-hal yang mengarah kepada perbuatan positif, karena apa yang diperoleh dalam rumah tangga remaja akan dibawa ke lingkungan masyarakat. Oleh karena itu pendidikan moral dalam keluarga penting sekali bagi remaja untuk menyelamatkan mereka dari kenakalan dan merupakan cara untuk mempersiapkan hari depan generasi yang akan datang, sebab kesalahan dalam pendidikan moral akan berakibat negatif terhadap remaja itu sendiri.

Pemahaman tentang agama sebaiknya dilakukan semenjak kecil, yaitu melalui kedua orang tua dengan cara memberikan pembinaan moral dan bimbingan tentang keagamaan, agar nantinya setelah mereka remaja bisa memilah baik buruk perbuatan yang ingin mereka lakukan sesuatu di setiap harinya seperti: (1) Menyediakan sarana-sarana dan menciptakan suasana yang optimal demi perkembangan pribadi yang wajar, (2) Memberikan wejangan secara umum dengan harapan dapat bermanfaat, (3) Memperkuat motivasi atau dorongan untuk bertingkah laku baik dan merangsang hubungan sosial yang baik. 
(4) Mengadakan kelompok diskusi dengan memberikan kesempatan mengemukakan pandangan dan pendapat para remaja dan memberikan pengarahan yang positif dan (5) Memperbaiki keadaan lingkungan sekitar, keadaan sosial keluarga maupun masyarakat di mana banyak terjadi kenakalan remaja.

\section{Tindakan Represif}

Usaha menindak pelanggaran norma-norma sosial dan moral dapat dilakukan dengan mengadakan hukuman terhadap setiap perbuatan pelanggaran. Dengan adanya sanksi tegas pelaku kenakalan remaja tersebut, diharapkan agar nantinya si pelaku tersebut "jera" dan tidak berbuat hal yang menyimpang lagi. Oleh karena itu, tindak lanjut harus ditegakkan melalui pidana atau hukuman secara langsung bagi yang melakukan kriminalitas tanpa pandang bulu. Sebagai contoh, remaja harus mentaati peraturan dan tata cara yang berlaku dalam keluarga. Disamping itu perlu adanya semacam hukuman yang dibuat oleh orangtua terhadap pelanggaran tata tertib dan tata cara keluarga. Pelaksanaan tata tertib harus dilakukan dengan konsisten. Setiap pelanggaran yang sama harus dikenakan sanksi yang sama. Sedangkan hak dan kewajiban anggota keluarga mengalami perubahan sesuai dengan perkembangan dan umur.

Di lingkungan sekolah, kepala sekolahlah yang berwenang dalam pelaksanan hukuman terhadap pelanggaran tata tertib sekolah. Dalam beberapa hal, guru juga berhak bertindak. Akan tetapi hukuman yang berat seperti skorsing maupun pengeluaran dari sekolah merupakan wewenang kepala sekolah. Guru dan staf pembimbing bertugas menyampaikan data mengenai pelanggaran dan kemungkinan-kemungkinan pelanggaran maupun akibatnya. Pada umumnya tindakan represif diberikan dalam bentuk memberikan peringatan secara lisan maupun tertulis kepada pelajar dan orang tua, melakukan pengawasan khusus oleh kepala sekolah dan tim guru atau pembimbing dan melarang bersekolah untuk sementara waktu (skors) atau seterusnya tergantung dari jenis pelanggaran tata tertib sekolah.

\section{Tindakan Kuratif dan Rehabilitasi}

Tindakan ini dilakukan setelah tindakan pencegahan lainnya dilaksanakan dan dianggap perlu mengubah tingkah laku pelanggar remaja itu dengan memberikan pendidikan lagi. Pendidikan diulangi melalui pembinaan secara khusus yang sering ditangani oleh suatu lembaga khusus maupun perorangan yang ahli dalam bidang ini.

Solusi internal bagi seorang remaja dalam mengendalikan kenakalan remaja antara lain: (1) Kegagalan mencapai identitas peran dan lemahnya kontrol diri bisa dicegah atau diatasi dengan prinsip keteladanan. Remaja harus bisa mendapatkan sebanyak mungkin figur orang-orang dewasa yang telah melampaui masa remajanya dengan baik juga mereka yang berhasil memperbaiki diri setelah 
sebelumnya gagal pada tahap ini Adanya motivasi dari keluarga, guru, teman sebaya untuk melakukan point pertama, (2) Remaja menyalurkan energinya dalam berbagai kegiatan positif, seperti berolahraga, melukis, mengikuti event perlombaan, dan penyaluran hobi, (3) Remaja pandai memilih teman dan lingkungan yang baik serta orangtua memberi arahan dengan siapa dan di komunitas mana remaja harus bergaul dan (4) Remaja membentuk ketahanan diri agar tidak mudah terpengaruh jika ternyata teman sebaya atau komunitas yang ada tidak sesuai dengan harapan.

\section{SIMPULAN}

Masa remaja erat kaitannya dengan berbagai fenomena - fenomena sosial pada perilaku remaja itu sendiri mulai dari perilaku yang baik maupun perilaku yang melanggar norma - norma sosial pada masyarakat. Masa remaja yang digunakan untuk mencari jati diri dan identitas diri sering dilakukan dengan metode coba - coba tanpa pertimbangan yang matang sehingga menimbulkan kesalahan yang menyebabkan terciptanya penyimpangan perilaku. Penelitian artikel ini dengan menggunakan metode kualitatif dengan menggunkan pendekatan studi kasus.

Penelitian kualitatif adalah penelitian yang bersifat deskriptif dan cenderung menggunakan analisis. Para ahli sependapat bahwa remaja adalah mereka yang berusia 13 - 18 tahun. Pada usia tersebut seseorang sudah melampaui batas anak - anak. Usia remaja juga terdiri dai bebarapa tahap yaitu (1) tahap pra-pubertas (12 - 13 tahun). Pada tahap ini, terjadi perubahan yang besar pada remaja, yaitu meningkatnya hormon seksualitas dan mulai berkembangnya organ-organ seksual serta organ-organ reproduksi remaja. (2) Tahap pubertas (14 - 16 tahun). Pada tahap ini, emosi remaja menjadi sangat labil akibat dari perkembangan hormon-hormon seksualnya yang begitu pesat.

Keinginan seksual juga mulai kuat muncul pada masa ini. (3) Tahap akhir pubertas (17 - 18 tahun). Pada tahap ini remaja yang mampu melewati masa sebelumnya dengan baik, akan dapat menerima kodratnya, baik sebagai laki-laki maupun perempuan. (4) Tahap remaja adolesen (19 - 21 tahun). Pada tahap ini remaja sudah mencapai kematangan yang sempurna, baik segi fisik, emosi, maupun psikisnya. Penyimpangan perilaku pada remaja disebabkan oleh perilaku eksternal, perilaku internal dan faktor tertentu. Solusi perilaku menyimpang pada remaja dapat diatasi dengan tindakan preventif (pencegahan), tindakan represif, tindakan kuratif dan rehabilitasi. 


\section{SARAN DAN REKOMENDASI}

Menurut penulis perlu dilakukan kerjasam yang baik antara orang tua remaja, tokoh-tokoh masyarakat seperti ketua $R T$, RW, Ustadz, dan tentu saja pemerintah. Supaya teratasi perilaku penyimpangan kenakalan remaja ini. Orang tua selaku pihak yang mempunyai peran besar untuk mengendalikan anak sebaik nya membentengi anak sejak dini melalui nilai nilai agama dan moral. Kemudian, tokoh - tokoh masyarakat selaku pihak yang mempunyai wewenang untuk mengendalikan masyarakat nya ada baik nya mengarahkan remaja kepada kegiatan - kegiatan positif seperti membentuk ikatan remaja masjid, memberikan sanksi tegas kepada remaja yang melakukan penyimpangan sosial dan lain sebagainya. Pemerintah terkhusus dinas sosial selaku pihak yang mempunyai wewenang untuk mengatasi masalah sosial ini juga harusnya ikut mengambil peran penuh terhadap kenakalan remaja baik itu di tingkat lorong, kecamatan, kelurahan bahkan kota.

\section{DAFTAR PUSTAKA}

Sumara, Dadan., Humaedi, Sahadi., dan Budiarto, Melani.S. 2017. Kenakalan Remaja dan Penanganannya. Universitas Padjajaran. Volume 4 Nomor 2.

Unayah, Nunun., Sabarisman, Muslim. 2015. Fenomena kenakalan remaja dan kriminalitas. Jakarta Timur.

Prasasti, Suci. 2017. Kenakalan remaja dan faktor penyebabnya. Universitas Tunas Pembangunan Surakarta.

Fikri, Sidiq Alima., Tri, Raharjo Santoso. Peran pendidikan karakter di masa remaja sebagai pencegahan kenakalan remaja. Universitas padjajaran Bandung. Volume 5 Nomor 2.

Gita, Lestari Erieske., Humaedi, sahadi., Melainny Budiarti .S., dan Hasannah, Desy. 2017. Universitas Padjajaran Bandung. Volume 4 Nomor 2. 